\title{
CONTRIBUTIONS OF LOCAL GUIDANCE PRACTICES TO THE NATURAL ENVIRONMENT, PROTECTED AREAS AND LOCAL PEOPLE
}

\author{
AKYOL, A. \\ Departmant of Forest Engineering, Faculty of Forestry, Suleyman Demirel University \\ 32260 Isparta, Turkey \\ e-mail: ayhanakyol@sdu.edu.tr; phone:+90-246-211-3937; fax: +90-246-211-3948
}

(Received $16^{\text {th }}$ Dec 2016; accepted $22^{\text {nd }}$ Mar 2017)

\begin{abstract}
In this study, local guidance practice's effects on the sustainable management of protected areas were investigated. Kaz Mountain National Park in Turkey was selected as the research site. Face-toface interview method was used in this study and semi-structured questionnaires were prepared for that purpose. The statistical analyses were done using SPSS 20 Statistics Package Program. Shapiro-Wilk-W test was used to check if the data were parametric $(p<0.05)$. The associations between the variables were analyzed by chi-square test. As a result of research, the education level increases, the participants have a higher tendency to demand the provision of more comprehensive and detailed education on local guidance. This is important to enable the local guides to better understand the ecological processes and convey them to the tourists. Other important finding was the fact that new job opportunities are created for local people living in the protected areas. In this way, local people hold the ownership of the protected areas and try to protect them. In conclusion, if provided in compliance with the rules, local guidance may have an effect on the sustainable management of the protected areas.
\end{abstract}

Keywords: environmental protection, sustainable tourism, residents, sustainable management, Turkey

\section{Introduction}

In parallel to the economic, political and technological developments in the last 5 decades across the world, the future of the natural environment has become an important matter on the agenda of developed and developing countries. The intensive use of natural resources for human welfare and economic growth leads to the contamination of ecosystems, loss of biological diversity and destruction of natural balance (Pickering and Hill, 2007; Lockwood et al., 2012; Kervankıran and Eryılmaz, 2014). As a result of such developments, the social and economic life of people has changed and their perspective to the nature has altered (Akyol et al., 2014). Recognizing the danger, the humanity has taken some measures and try to find the ways to mitigate the losses (Tolunay and Akyol, 2015). Such measures include primarily the conservation and sustainable management of the vulnerable ecosystems (Pullin and Knight, 2005; Buckley et al., 2008; Tolunay et al., 2014).

The system of parks and protected areas is considered to be an important component of global conservation strategies (Wells and Mcshane, 2004; Bajracharya et al., 2005; McGeoch, 2016). Moreover, these areas serve to the fulfilment of social and economic functions such as rural development, recreation-tourism and education-research in addition to the environmental and ecological functions (Yildirım and Yurdakul, 2012; Suich et al., 2015; IUCN, 2015). The attention is now more focused on the protected areas particularly due to the changing approach to the mass tourism and tendency to move away from the usual tourism attractions (Marzouki et al., 2012). Such an increased interest has led to the emergence of the concept of ecotourism since ecotourism adopts the principles of protecting the natural areas, providing economic 
contributions to local people and living in an environmentally-conscious manner (Bushell and Eagles, 2007; Korkmaz and Başkalkan, 2011; Akyol and Tolunay, 2012; Wang, 2014).

The General Directorate Nature Conservation and Natural Parks (GDNP) that is the governmental body in charge of managing the protected areas in Turkey on one hand identifies and declares the protected areas with different statuses while on the other hand prepares the management plants for such areas (Alkan and Korkmaz, 2009). However, a participatory approach was not adopted in the preparation of such plans especially during the initial years and thus several problems have occurred today (Alkan et al., 2009; Calvet-Mir et al., 2015).

One of the most important problems is the complexity of protecting the natural ecosystem on one hand while on the other hand allowing the recreational activities in or touristic use of the same areas (Pickering and Hill, 2007; Kuss and Graefe, 1985; Liddle, 1997). Today, the basic protection justifications of the areas that are protected by laws in scientific and technical sense usually conflict and thus fail to compete with especially the recreational or tourism purposes. Therefore, the natural and cultural assets that are intended to be protected are negatively influenced (Gül and Akten, 2005). This necessitates the development of new policies for the control and management of the factors that affect the resource values in areas where intensive recreational use conflicts with the protection purpose (Absher, 1989; Kuss et al., 1990; Akten et al., 2012; Jones et al., 2016).

Another problem is the relationship between the protected areas and local people (Alkan, 2009). In general, the source of living and cultural assets of local people depend on the resources in the protected areas (Trakolis, 2001; Tolunay and Alkan, 2008; Badola et al., 2012). However, this has not been taken into account in the current practices and several areas having capacity of production forest have been accorded the protected area status. The local resource users who were not consulted and informed during the decision-making process not only were subjected to prohibitions but also lost their means of livelihood based on forest resources (Özden et al., 2001; Soykan and Ar1, 2004; Törn et al., 2007; Dudley, 2008; Yurdakul et al., 2011).

In conclusion, since ecotourism and recreation have gained importance, "By-Law on the Selection, Training, Working Procedures and Principles of Local Guides" was enacted in 2006 with a view to striking the balance with protection and use of protected areas, informing and managing the visitors and creating employment for local people (RG, 2016a). Therefore, people have been allowed to travel to the natural areas individually or in small groups while the goal was to prevent the environmental destruction thanks to the controlled tours and enable the local people to generate economic income (Arslan, 2005). The abovementioned By-Law defines "local guide" as a person who provides accurate and reliable information to the visitors within the boundaries of protected areas. Hence, the local guides inform the visitors about the biological diversity, geodiversity, ecosystem, endemic species, culture and history of the national parks and are responsible for the protection of the area throughout the activities (Temizkan and Yıldırım, 2014).

In this context, the purpose of this study was to determine the current status of local guidance practice in Turkey and its effects on the sustainable management of the protected areas. 


\section{Materials and methods}

\section{Description of the research site}

The research was implemented in Kaz Mountain National Park (KMNP) and included the 37 local guides working there. This National Park is located (Fig. 1) within the boundaries of Balıkesir province in the transition zone of Marmara and Aegean Regions (Ar1 and Soykan, 2006a; GDNP, 2016). With its biological diversity, geomorphological features, endemic species, water resources and cultural and archaeological resource values, Kaz Mountain was designated as national park upon the Cabinet Decree promulgated in the Official Gazette numbered 21555 on 17.04.1994. Its surface area is 20935 ha while it is the highest mountain of Biga peninsula. The highest point of the mountain is Karataş Tepe (Gargaros) at an elevation of $1774 \mathrm{~m}$. The northern border of KMNP passes through the peak of the mountain in a way to overlap with the demarcation of the provincial management to facilitate the management of the park while its southern border is drawn to pass along the residential areas and east-west borders are defined by the river valleys (GDNP, 2016; BIKTTM, 2016).

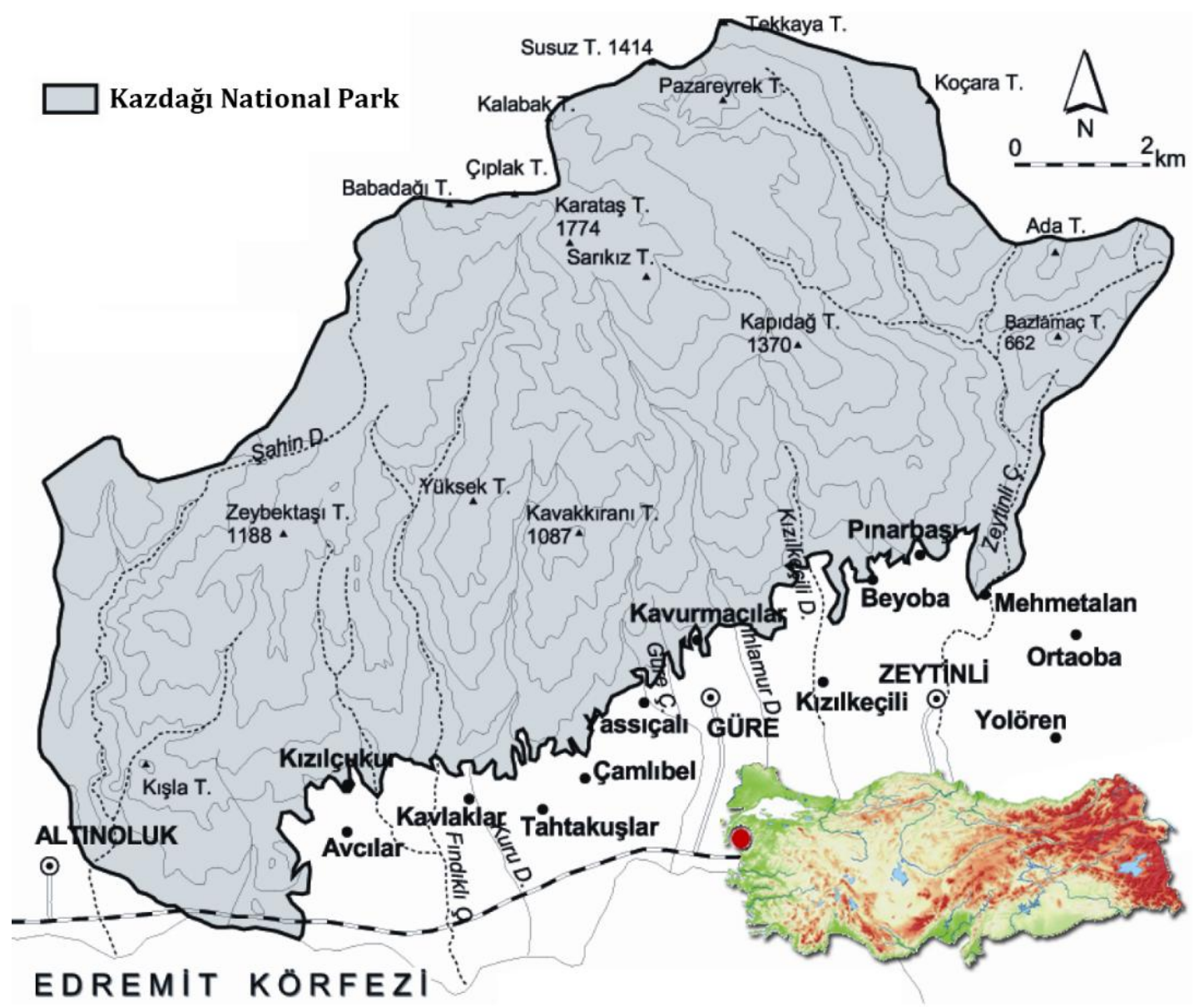

Figure 1. Map of the study area

The resource values of KMNP are comprised of very different elements. The most important elements are the biological diversity and cultural assets in the park. Studies conducted in the national park show that 32 out of 800 plant species identified are 
endemic only to Kaz Mountain Regions (Ar1 and Soykan, 2006a; Dirmenci et al., 2004; Sat1l et al., 2006). Abies nordmanniana subsp. equitrojani that is an endemic plant species is widely distributed outside the national park, while this distribution area of 250 ha is designated as a nature conservation area (GDNP, 2016). The other most wellknown endemic plant species Thymus pulvinatus and Sideritis trojana. The dominant tree species in the forest cover include brutian pine (Pinus brutia), oak (Quercus sp.) and black pine (Pinus nigra). On the other hand, the species that form communities mixed with the abovementioned species include chestnut (Castanea sativa), beech (Fagus orientalis), Abies nordmanniana subsp. equitrojani and poplar (Populus tremula) (Tağıl, 2006). As regards the fauna of the park, 18 mammalian species, 21 amphibian, 100 reptile species, 10 fresh water fish species and 82 bird species were identified within the park (GDNP 2016; Ar1 and Soykan, 2006b).

Referred to as "Ida with a thousand springs" in the mythology, Kaz Mountain is surrounded by archaeological settlement areas such as Thebe, Killa, Khrysa, Anderia, Adramyttion, Antandros, Assos, Pedosos and Astrya. Today, there are 13 residential areas outside the boundaries of KMNP but located just adjacent to the park and utilizing the park's resources in daily life (GDNP, 2016).

\section{Data collection and statistical analysis}

The research data were obtained through face-to-face interview. Interview is used as an effective data collection method in several fields of science. In this research, semistructured interview method was selected as an interview technique. The purpose of the semi-structured interview is to identify the similarities and differences between the information given by the interviewers, make comparisons and enable the interviewers to be flexible regarding the matters discussed during the interview (Yüksel et al., 2007). The field application was realized using the questionnaires prepared for that purpose to conduct individual interviews. The success of the interview depends on the collection of information regarding the problem; therefore, it is important that the researchers have the adequate theoretical knowledge about matter to be studied (İslamoğlu, 2009). The statistical analyses were done using SPSS 20 Statistics Package Program. The responses given are presented as percentage and frequency in the tables in this study in order to assess the data collected. To check if the data were parametric, Shapiro-Wilk-W test that is stronger than Kolmogrov-Smirnov test was used and it was found that the data did not have a normal distribution with a confidence interval of $95 \%(\mathrm{p}<0.05)$, in other words, the data were not parametric (Mendes and Pala, 2003). Therefore, chi-square test (CST) was used to analyze the associations between the variables. Throughout the research, information obtained through literature review as well as the information, documents, maps, papers, statistical data and reports obtained from various public bodies were also used.

First, laws and regulations regarding local guides and the amendments there to were analyzed in the study, which provided a concrete base. Then, a preliminary study was conducted in KMNP and semi-structure questionnaires consisting of 35 questions were prepared according to the results of the preliminary study. After, the local guides working in KMNP were interviewed in July-September 2015. 


\section{Results}

\section{Demographic structure}

There are 37 local guides working at KMNP. The interviews were held with a total of 31 local guides. 6 local guides could not be interviewed due to various reasons (they were not working, they were on leave and reluctant). The demographic data of the respondents are presented in Table 1.

Table 1. Demographic data of participants

\begin{tabular}{clcc}
\hline Features & Groups & $\boldsymbol{f}$ & $\mathbf{( \% )}$ \\
\hline Gender & Male & 31 & 100.0 \\
\hline \multirow{4}{*}{ Age } & $18-30$ & 2 & 6.5 \\
& $31-40$ & 12 & 38.7 \\
& $41-50$ & 5 & 16.1 \\
& $51-60$ & 10 & 32.3 \\
& $61<$ & 2 & 6.5 \\
\hline Marital Status & Married & 27 & 87.1 \\
& Single & 4 & 12.9 \\
\hline \multirow{2}{*}{ Education } & High school & 15 & 48.4 \\
& University & 16 & 51.6 \\
\hline \multirow{3}{*}{ Income Level $(\$)$} & $0-350$ & 10 & 32.3 \\
& $351-700$ & 4 & 12.9 \\
& $701-1050$ & 2 & 6.5 \\
& $1051-1400$ & 11 & 35.5 \\
& $1401<$ & 4 & 12.9 \\
\hline
\end{tabular}

All of the respondents were male because of the fact that all the local guides working at the national park were male. But there is no obstacle for women not to work. It has also been learned from the park management that some women candidates are preparing to apply for new courses. Since any person younger than 18 is not allowed to work as a local guide as per the law, the age groups started from 18 years of age and five different age groups were formed. $38.7 \%$ of the respondents were in 31-40 age group while $32.3 \%$ were in 51-60 age group. Most average are older that means more experience and knowledge. As regards the educational background, nearly half of the respondents were high school graduates while the other half was university graduate. High education that qualifies workers to this job, which requires reading, speaking, languages, empathy and not only physical conditions. With regard to the marital status, $87.1 \%$ of the respondents were married while $12.9 \%$ were single. It is also that indicates a society that believes in marriage, in family, and/or a class of job that believes in it way of live.

The data regarding the income generated by the local guides in 2015 show that $32.3 \%$ of the guides earned 0-350 US\$, $12.9 \%$ earned 351-700 US\$, 6.5\% earned 7011050 US\$, 35.5\% earned 1051-1400 US\$ and 12.9\% earned 1401 US\$ and more. The minimum wage is approximately 600 US\$, per month in Turkey (CSGB, 2016). This is 7200 US\$ a year. This reveals that all of the respondents earn income below the minimum wage.

\section{Training}

One of the main themes of the study was the training of local guides. The data collected in the study revealed that all of the local guides received local guide training 
as per the relevant laws. The education was provided in line with the program developed jointly by the GDNP, Balıkesir University and Çanakkale On Sekiz Mart University. Moreover, one of the local guides interviewed participated in the Environmental Training Program of the Scientific and Technological Research Council of Turkey (TÜBİTAK). The training of local guides consisted of two stages which were theoretical and practical and took 1 month. At the end of the training, the participants received "Local Guides ID and Certificate". The training covered the flora, fauna, geology, mythology, sociology, anthropology, cultural structure, history, first aid and compass-navigation.

The participants were asked what they thought about the adequacy of the local guide training they received and $61.3 \%$ of the respondents reported that the training was adequate. Table 2 shows that $32.3 \%$ of the respondents found their training partially adequate while $6.5 \%$ found it inadequate.

Table 2. Adequacy of local guide training and need for more comprehensive training

\begin{tabular}{clrr}
\hline Question & \multicolumn{1}{c}{ Answers } & \multicolumn{1}{c}{$\boldsymbol{f}$} & $\mathbf{( \% )}$ \\
\hline \multirow{3}{*}{ Adequacy of the training } & Adequate & 19 & 61.3 \\
& Partially adequate & 10 & 32.3 \\
& Inadequate & 2 & 6.5 \\
\hline More comprehensive & Yes & 25 & 80.6 \\
training & No & 6 & 19.4 \\
\hline
\end{tabular}

In this context, $80.6 \%$ of the respondents wanted to receive more comprehensive training, while $19.4 \%$ of the participants did not want to receive more comprehensive training. The results of the CST are presented in Table 3. Table 3 shows the analysis of the answers given by the respondents based on some profile categories. There is no association between the age of the respondents and their opinion that the training was adequate. However, an association was found between the age of the respondents and their need for more comprehensive training. As the age of the respondents advanced, they tended to state that more comprehensive training should be given.

Table 3. Association between some profile categories and local guide training

\begin{tabular}{clrcc}
\hline Profile categories & \multicolumn{1}{c}{ Factors } & \multicolumn{1}{c}{$\boldsymbol{x}^{2}$} & sd & \multicolumn{1}{c}{$\mathbf{p}^{*}$} \\
\hline \multirow{2}{*}{ Age } & Adequacy of the training & 7.549 & 8 & .479 \\
& More comprehensive training & 11.780 & 4 & $.019^{*}$ \\
\hline \multirow{2}{*}{ Education } & Adequacy of the training & 12.644 & 2 & $.002^{*}$ \\
& More comprehensive training & 7.936 & 1 & $.005^{*}$ \\
\hline \multirow{2}{*}{ Marital status } & Adequacy of the training & .512 & 2 & .774 \\
& More comprehensive training & 2.763 & 1 & .096 \\
\hline \multirow{2}{*}{$\mathrm{P}^{*}=\mathrm{P}<0.05$} & & & &
\end{tabular}

The participants were categorized into two groups that are high-school graduates and university graduates as shown in Table 1. The results of the CST revealed that there was an association between the education level of the respondents and the adequacy of the local guide training and more comprehensive training need. The university graduate respondents stated that the local guide training should be more comprehensive. In 
another word, as the education level increases, the respondents tended to think that the local guide training should be more comprehensive and detailed. So they will become specialized. Considering age and education level together, younger and high-school graduate respondents found the training adequate, whereas the older and university graduate respondents did not find the training adequate and thought that more comprehensive training was needed.

The results of the CST analysis did not reveal any association between the marital status of the respondents and the adequacy of the training and more comprehensive training need.

\section{Income}

The interview questionnaires prepared for the research also included questions to assess the income level of the local guides. All of the participants included in the study pursue the profession of local guide to generate additional income. The annual average income earned by the respondents as local guides in 2015 was around 807 US\$. So, about 67.5 US\$ per month. But this is not good income in Turkey conditions. For this reason, all of the local guides need to have a second job (Table 4).

Table 4. Some profile data regarding the employment status of the participants

\begin{tabular}{clrr}
\hline Profile Data & Groups & $\boldsymbol{f}$ & $\mathbf{( \% )}$ \\
\hline & Retired & 9 & 29.0 \\
\multirow{5}{*}{ Sectors } & Agriculture & 10 & 32.3 \\
& Tourism & 3 & 9.7 \\
& Agriculture, tourism, retirement & 9 & 29.0 \\
\hline \multirow{2}{*}{ Duration in } & $0-5$ & 1 & 3.2 \\
profession & $6-10$ & 26 & 83.9 \\
& $11<$ & 4 & 12.9 \\
\hline Annual & $0-25$ & 12 & 38.7 \\
average & $26-50$ & 9 & 29.0 \\
number of & $51-75$ & 6 & 19.4 \\
activities & $76<$ & 4 & 12.9 \\
\hline Financially & Yes & 13 & 41.9 \\
satisfied & No & 18 & 58.1 \\
\hline & & &
\end{tabular}

Table 4 shows that $29 \%$ of the respondents were retired, while $32.3 \%$ were engaged in agriculture, $9.7 \%$ were engaged in tourism whereas $29 \%$ of the participants reported that they had multiple sources of income (agriculture, tourism, retirement). Table 5 presents the CST analysis of the association between the profile of the respondents and the income generated from local guidance.

Table 5 reveals that there was an association between the age of the respondents and the primary source of income, while there was no association between the age groups and annual average income and financial satisfaction levels. According to the analysis performed, it seems that as the age of the participants' advances, they are more engaged in multiple lines of work.

There wasn't any association between the education level of the respondents and their primary source of income, annual average income and financial satisfaction levels. 
Table 5. Associations between the profiles of the respondents and their income generated from local guidance and sources of income

\begin{tabular}{clrrl}
\hline Profile & \multicolumn{1}{c}{ Factors } & \multicolumn{1}{c}{$\boldsymbol{x}^{2}$} & \multicolumn{1}{c}{ sd } & \multicolumn{1}{c}{$\mathbf{p}^{*}$} \\
\hline \multirow{3}{*}{ Age } & Primary source of income & 21.970 & 12 & $.038^{*}$ \\
& Annual average income & 24.845 & 16 & .073 \\
& Financial satisfaction level & 2.184 & 4 & .702 \\
\hline \multirow{3}{*}{ Education } & Primary source of income & 5,907 & 3 & .116 \\
& Annual average income & 2.061 & 4 & .725 \\
& Financial satisfaction level & .045 & 1 & .833 \\
\hline \multirow{3}{*}{ Marital status } & Primary source of income & 9.150 & 3 & $.027^{*}$ \\
& Annual average income & 4.912 & 4 & .296 \\
& Financial satisfaction level & .541 & 1 & .462 \\
\hline
\end{tabular}

$\mathrm{P} *=\mathrm{P}<0.05$

According to the results of the CST, there was an association between the marital status and primary source of income. The analysis revealed that single respondents were interested more in the tourism sector. Since the income generated in the tourism sector is seasonal, the married respondents preferred more reliable sectors. So, tourism is a kind of leisure and recreation to youngers without commitments such as family. However, there wasn't any association between the marital status of the respondents and their annual average income and financial satisfaction levels.

As regards the financial and non-pecuniary satisfaction of the respondents with the profession of local guide, they reported that they were highly satisfied from nonpecuniary perspective. However, as Table 4 indicates, $58.1 \%$ of the respondents stated that the financial income generated from local guidance was not sufficient and they did not have any security working as local guide. They also stated that they did this job just because they loved the nature and the region they lived in and due to the spiritual satisfaction they derive out of this job.

With regard to their duration in the profession, $3.2 \%$ of the respondents had been working as local guide for $0-5$ years, $83.9 \%$ had been working for 6-10 years and $12.9 \%$ had been working for more than 11 years, while they worked as local guides for 38 times in a year on average. This corresponds to approximately 3 times a month. The intensity of work in the summer season is increasing due to the increase in the number of visitors.

\section{Managerial matters}

Table 6 presents the results of the assessment regarding the managerial matters. Local guides and the services they provide are inspected directly by the national park management. Furthermore, The Association of Local Guides of KMNP established by the local guides performs internal control on the services provided. In this scope, as Table 6 indicates, $41.9 \%$ of the respondents reported that they experienced problems with the inspecting authority, while $58.1 \%$ stated that they did not have any problems with it. Those who problems had reported that the main problems were related to poor education level of the national park staff, lack of trust in the local guides and infrastructure insufficiencies. For the solution of the problems, they suggested that the infrastructure insufficiencies in the national park should be overcome, the national park staff should be trained better and the number of the national park staff should be increased, the excursion routes should be readjusted and illegal entries should be 
prevented. Basic the same problems found in protected areas, according (Buckley, 2003; Stone and Nyaupane, 2016).

As regards the relationship of the respondents with the national park staff, $61.3 \%$ of the respondents were satisfied with the mutual relations. However, $38.7 \%$ reported that they were not satisfied. Those who were not satisfied stated that they felt uncomfortable especially due to the lack of trust of the national park staff in local guides.

With regard to the question whether the existing excursion and hiking routes identified in the national park were convenient, $35.5 \%$ of the respondents found the routes convenient, whereas $64.5 \%$ did not. Those who did not find the routes convenient stated that there were different excursion routes in the area, they could not be connected and those routes were not enough to experience the area. Within this context, $90.3 \%$ of the participants thought that the excursion routes had to be readjusted jointly by the national park management and the Association of Local Guides park taking account of the ecological and geomorphological features of the area $(54.8 \%)$, security of the visitors $(25.8 \%)$ and requests of visitors $(19.4 \%)$.

The respondents were also asked to assess their relationship with the Association of Local Guides of KMNP that they are a member, and $58.1 \%$ of them reported that they were not satisfied with the activities of the association while $41.9 \%$ stated that they were satisfied with the activities of the association. Those who were not satisfied stated that in particular the association could not defend the rights of its members and the duty list it prepared was not fair. They also expressed their views that some local guides often times failed to comply with the duty list, which led to interruptions in the service provided.

Table 6. Local guides, national parks management and relations between them

\begin{tabular}{llrr}
\hline \multicolumn{1}{c}{ Questions } & Answers & $\boldsymbol{f}$ & $\mathbf{( \% )}$ \\
\hline Problems experienced with the & Yes & 13 & 41.9 \\
inspecting authority (NP) & No & 18 & 58.1 \\
\hline \multirow{2}{*}{ Relations with the staff of NP } & Satisfied & 19 & 61.3 \\
& Not satisfied & 12 & 38.7 \\
\hline Convenience of the excursion & Yes & 11 & 35.5 \\
routes & No & 20 & 64.5 \\
\hline Who should determine the & NP management & 3 & 9.7 \\
routes & NP management and local guides & 28 & 90.3 \\
\hline \multirow{2}{*}{$\begin{array}{l}\text { Matters to take into account } \\
\text { while determining the routes }\end{array}$} & Ecologic and geomorphologic features & 17 & 54.8 \\
& Security of visitors & 8 & 25.8 \\
\hline Activities of the association of & Demands of visitors & 6 & 19.4 \\
\hline local guides & Satisfied & 13 & 41.9 \\
\hline Cooperation with the other & Not satisfied & 18 & 58.1 \\
local guides & Yes & 7 & 22.6 \\
\hline Cooperation with the tourism & No & 24 & 77.4 \\
\hline agencies & Yes & 10 & 32.3 \\
\hline
\end{tabular}

As regards the assessment of the relationships with the other local guides and associations, $22.6 \%$ of the respondents stated that they cooperated and exchanged views with the other associations, whereas $77.4 \%$ reported that they did not cooperate and exchange views with them. When the respondents were asked about their relationships with the tourism agencies in the region, $32.3 \%$ of them responded that they cooperated 
with the tourism agencies, while $67.7 \%$ did not cooperate with the tourism agencies. Most part of local guides prefer to build their own walking tours considering tourist needs, despites package tours of travel agencies. The respondents suggested that the association of which they were a member should work more actively on this matter and conclude mutual agreements with the tourism agencies. Moreover, the respondents also stated that they were occasionally involved in some activities conducted by the naturerelated associations, training institutions, private companies and researchers at different organizations at individual level.

According to the CST performed to see if there was an association between the profile of the participants (age, educational background and marital status) and the parameters indicated in Table 6, there was no association between the age, educational background and marital status of the participants and the parameters shown in Table 6.

\section{Protection}

Protection is one of the keys in designating an area as a protected area. The grounds for protection basically focus on two criteria. The first criterion is that there must be a resource in the area that is worth protecting. The second criterion is the uncertainty in the area. In particular, as the complexity of the relationships in the ecosystems increases, the uncertainty of every unidentified variable also increases. As a matter of behavior, people are afraid and skeptical of uncertain phenomena that they cannot explain and define. The simplest solution found for this is to designate the area as protected area and minimize the human interventions in the area until the uncertainties are identified and reduced. However, tourism in protected areas where the uncertainty factor is high may damage the complex relationships in the ecosystem including primarily biological diversity. Therefore, the practice of local guidance draws attention as a tool to strike the balance between protection and use in the protected areas. For this reason, the local guides were also asked what they thought about the protection of the area in this study.

The assessments performed revealed that all of the participants thought that there were problems faced regarding the protection of the area. The participants were of the opinion that the most important problem faced in the protection of the area was the illegal entry into the national park. Common in parks without infrastructure and human resources to build more entrances and fences and walls. Or, community and tourist needs to get in illegally (costs, not recognizing of park, etc.). They stated that there were intensive illegal entries especially at the border with Çanakkale province that is located on the north of the national park. Illegal plant collection and illegal hunting activities, insufficient number of national park staff and problems associated with the utilization of the park area by the local people were the other issues expressed by the respondents. The results of CST regarding the participants' views about protection are shown in Table 7.

The problems associated with the protection of the area were grouped under 4 categories, which were lack of staff, illegal hunting, illegal plant collection and illegal entry into the area. The protection purposes of the local guides were grouped under 4 categories, which were generation of income, legal obligations, loving the nature and living in the vicinity of the area. The results of the CST performed in the light of these data revealed that there was an association between the age of the respondents and their views about illegal hunting and illegal plant collection. Participants who were in the age group 51-60 were of the opinion that lack of staff and illegal entry into the park were 
more important that illegal hunting and illegal plant collection. However, no association was found between the age of the respondents and the NP protection purposes.

Table 7. Associations between the local guides and protection of the national park

\begin{tabular}{|c|c|c|c|c|c|}
\hline Profile & & Factors & $x^{2}$ & sd & $\mathbf{p}^{*}$ \\
\hline \multirow{8}{*}{ Age } & \multirow{4}{*}{$\begin{array}{l}\text { NP protection } \\
\text { problems }\end{array}$} & Lack of staff & 4.687 & 4 & .321 \\
\hline & & Illegal hunting & 9.950 & 4 & $.041 *$ \\
\hline & & Illegal plant collection & 10.834 & 4 & $.028 *$ \\
\hline & & Illegal entry & 9.460 & 4 & .051 \\
\hline & \multirow{4}{*}{$\begin{array}{l}\text { NP protection } \\
\text { purposes }\end{array}$} & I generate income & 1.926 & 4 & .749 \\
\hline & & I have a legal obligation & 5.526 & 4 & .237 \\
\hline & & I love the nature & 1.636 & 4 & .802 \\
\hline & & I live in this vicinity & 2.904 & 4 & .574 \\
\hline
\end{tabular}

On the other hand, there was no statistically significant association between the marital status and educational background of the participants and NP protection problems and NP protection purposes. However, the participants stated during the interview that they loved the nature, the lived in the vicinity of the national park and they wanted to pass these natural beauties down to their children. These views indicate that the local guides working in the protected areas had high level of awareness about the protection of the park. Feeling of heritage, legacy it is important to cultural (local guidance) and natural (park) preservation and conservation. They supported the protection of the park in the following ways:

- Intervening in the illegal entries (notify),

- Collecting the solid wastes in the national park,

- Warning people about the fire danger,

- Raising the awareness of the local people,

- Intervening in illegal hunting and illegal plant collection (notify) and

- Helping the fire brigade crew on a voluntary basis in case of fire.

\section{Legal assessment}

Following the "KMNP Ecotourism Guides Training Seminar" organized in 2002 in Turkey, the local guides started working in KMNP. In the same period, similar developments took place in Gallipoli Peninsula Historical National Park. The Chambers of Professional Tourist Guides had a reaction to all these developments. In order to overcome these reactions, the legal instrument required for the performance of the local guides was drafted, article 16 of the Law no 2873 was amended in 2005 and "By-Law on the Selection, Training, Working Procedures and Principles of Local Guides" was enacted in 2006. However, the Chambers of Professional Tourist Guides and the Association of Turkish Travel Agencies (TÜRSAB) brought an action before the Council of State for the stay of execution and annulment of the concerned by-law on 5 June 2006 to show their reactions to the practice of local guidance (Atay, 2006, 2008).

On the other hand, "By-Law on Amendment to the By-Law on the Selection, Training, Working Procedures and Principles of Local Guides" promulgated on the Official Gazette no 27679 dated 21.08.2010 introduced some amendments to certain provisions of the by-law enacted in 2006 , which substantially increased the authorities, 
duties and responsibilities of the local guides before the administration. Pursuant to the concerned amendments (RG, 2016b).

Article 20, paragraph 1, sub-paragraph "e" of the By-Law was amended as "Visitors entering into the protected areas in groups (comprised of 12 people and more) or agencies organizing activities in the protected areas shall be obliged to use a local guide for their visits and activities in the protected areas even though they have their own guides". This amendment authorized only the local guides for the activities carried out in the protected areas.

Article 20, paragraph 1, sub-paragraph "g" of the By-Law was amended as "the local guides shall be directly accountable to the administration for the guidance services they provide in the protected areas and the consequences of such provision of services. If an organization is established, the local guides shall be accountable to the organization and the organization shall be accountable to the administration". In this amendment, "organization" refers to any association, cooperative, foundation or similar organizations founded by the local guides or the structure representing all the organizations if multiple of them are founded.

The amendment introduced to Article 20, paragraph 1, sub-paragraph " $\breve{g}$ " imposes on the local guides the obligation to wear the clothes determined by the Directorate General, while the amendment made to sub-paragraph " $h$ " introduces the requirement for the local guides to comply with the communiqués, circulars and instructions to be issued by the Ministry in addition to this By-Law.

Pursuant to the amendment made to Article 20, paragraph 1, sub-paragraph "1", "local guides shall have to prevent any acts that may threaten the resources and biological diversity of the area during the activities. Local guides and visitors shall not be allowed to act in a way to damage the nature and wild life during the activities. Wild animals, plants, flowers, seedlings, flower bulbs, fruits, branches, roots, stones, soil and similar materials in the area cannot be collected and taken outside of the area. Local guides shall have the obligation to prevent, if possible, any negative events that may damage the resources of the area including the visitors that they provide guidance service, or if not possible, issue the necessary reports or minutes against the persons who lead to such negative events and immediately notify the administration or the organization they are affiliated to". This amendment assigns important duties and responsibilities to the local guides with respect to the protection of the area and prevention of bio-smuggling.

Moreover, as per the amendments introduced, the criteria to be fulfilled to pursue the profession of local guide were stipulated as being Turkish national, being minimum high-school graduate; residing within the boundaries or in close vicinity of the protected area at least for one year; being older than 18 years of age on the application date; not being prisoned for more than 6 months or convicted of crimes committed against the personality of the state although they were pardoned, of disgraceful offences or dishonorable and degrading offences such as embezzlement, malversation, bribery, larceny, swindling, forgery and fraud, misuse of faith, fraudulent bankruptcy or of the crimes of smuggling, rigging official tenders and procurements, disclosing state secrets; and not being employed as a worker or civil servant in the public sector (Temizkan and Y1ldirım, 2014). 


\section{Discussion and conclusion}

Upon the entry into force of the National Parks Law no 2873 in 1983 in Turkey, the number and coverage of the national parks designated with various statuses has increased rapidly. However, since many forestlands used for production purposes previously were designated as protected areas, the forest-based mainstay of local people living in those areas was restricted and their pressure on natural resources increased gradually. Combined with the increased tourism pressure with the advent of ecotourism and recreation, these developments resulted in several problems associated with the sustainable management of these areas.

As a consequence of all these developments, the by-law on the selection, training, working procedures and principles of local guides was enacted with a view to ensuring the protection of these special areas, providing information to the visitors, managing the visitors and creating employment for local people. As per the by-law, local guide is defined as a person from local people who is awarded with a certificate and ID card following the training s/he receives, assists the management of the visitors in the protected areas and provides information to the visitors. As per the concerned by-law, local guides fulfil some main functions such as protecting the area, informing the tourists visiting the area, providing socio-economic benefits to the local people, promoting the culture of local people residing in the area, and managing the visitors in the protected area. Similar to Rangers in the National Parks Service of USA.

Following the training courses and exams organized in line with the relevant by-law for KMNP, 37 people were certified as local guides, who then founded the Association of Local Guides of Kaz Mountain National Park on 25.08.2008 (KMPAKD, 2016). The association is still actively operating and provides corporate communication through their web page.

Although the practice of local guidance implemented in the national parks in Turkey vary across national parks in the world, there are similar cases as well. For example, Mutawintji National Park in New South Wales can only be visited only in the accompany of authorized guides. This is a mandatory in most part of Geoparks (GGN, 2016). To be a guide in that park, one has to complete the tour guide training organized by the Local Aborigine Land Council and National Parks and Wild Life Services and be awarded with the certificate (Howard et al., 2001).

Another important example is Masola National Park in the Madagascar. This park is managed jointly by an organization half of which is owned by the state and a nongovernmental organization. Furthermore, another important feature of the park is that there is a dedicated association of local ecotourism guides (Orsmby and Mannle, 2006). Tourist have to be accompanied by a guide during their visits to Masoala National Park. To be a guide in the national park, candidates have to pass the written and verbal exams recognized by the association and speak at least one more foreign language fluently in addition to French and Malagasy language. The basic duty of a guide is to provide information to the visitors about the existing local plants and animals, history and cultural features of the area. Besides, the park guides are also responsible for the protection of the environment and prevention of removal of plant and animal species outside the park and safeguarding their security by ensuring that the visitors follow specific routes. Furthermore, half of the entrance fees collected for the park is allocated to the local management committees for improvement projects. This serves to the balance between protection and use (Orsmby and Mannle, 2006). 
This study conducted in KMNP demonstrated that the practice of local guidance service was one of the most concrete steps taken to prevent the problems faced with the local people residing within the protected areas. The importance of local guidance becomes more obvious considering that it creates employment for local people and is a practical way. Moreover, the selection of local guides among the local people contributes to the awareness raising of local people about protection. In this contributes to the increased ownership of the protected areas by local people and thus its protection. However, there are some problems experienced by the local guides. The relevant parties should take concrete steps to solve such problems with a participatory approach and the practice of local guidance should be made more effective and efficient. At this stage, analysis of the guidance practices in different countries would provide significant contributions to increase the success of local guidance practices.

From the perspective of sustainable tourism principles, local guidance in the protected areas will also contribute to striking the balance between the protection and use of natural resources. In particular, it is considered that well-educated local guides will play an effective role in the prevention of illegal hunting, illegal plant collection and increased tourism pressure. In this scope, "By-Law on Amendment to the By-Law on the Selection, Training, Working Procedures and Principles of Local Guides" enacted on 21.08.2010 substantially increased the authorities, duties and responsibilities of local guides before the administration. As regards the criteria laid down in the by-law to be a local guide, the by-law stipulates very high standards for this subject-matter and is not problematic in this regard.

It was found out in the study that there was a high demand and pressure on the national park management to organize a new training seminar for local guides in KMNP. The relevant by-law stipulates that the local guide training shall be comprised of theoretical and practical phases. However, the training itself and the training topics to be delivered the local guides should be reviewed in order to raise the standards and they should be supported through periodical in-service training, which will collectively increase the trust in local guides and quality of the service provided. Furthermore, better provision of information about the complex relationships in natural ecosystems to the local guides through training will provide an important contribution to the protection of biological diversity, geodiversity and thus ecosystem. As the educational level of the participants increases, the training to be provided should be more comprehensive, which was demonstrated by the statistical association found to have the significance level of $\mathrm{p}<0.05$. This finding is important to enable the local guides to better understand the ecological processes and relationships and convey them to the tourists. If support is obtained for the training from the Faculties of Forest and Tourism that have scientific research areas such as ecology, ecotourism and humans, this will significantly contribute to the training.

It was found out in the study that local guidance generated additional source of income, and the local guides were spiritually satisfied but not financially satisfied. However, the respondents insistently emphasized that their non-pecuniary satisfaction and inner peace could not be expressed with money. This finding can be used as a tool to motivate the local guides for protection of the area and improvement of the quality of the service they provide. Furthermore, the Association of Local Guides of KMNP may increase the service quality and annual average number of activities through the strategies it will develop in collaboration with the national park management and local 
guides. Such an increase in turn would increase the income to be generated from the practice of local guidance.

In general, the local guides interviewed were of the opinion that

- the number of national park staff should be increased,

- the infrastructure and superstructure of the national park should be improved (entrance control gates, WC, social facilities etc.),

- the area should be monitored more carefully against the risk of fire,

- the system of accident insurance for visitors should be put in place,

- collaboration with the tourism agencies in the region should be improved,

- local guides should be granted with social security,

- the excursion routes in the national park should be reviewed,

- an effective system of communication between the local guides should be established and

- trust in local guides should be increased.

In conclusion, the implementation of the abovementioned recommendations will have an a positive impact on the prevention of conflicts with local people residing in the protected areas, solution of the problems, increasing the financial satisfaction of the local guides, striking the balance between the protection and use of the area and improvement of the quality of service provided by the local guides. Or should rethinking the category of protected area and its management (IUCN, 2016). Moreover, private management established by the local guide (New Association of Local Guides) can be proposed instead of the government.

Another theme that can be discussed it is about Berkes (2012) calls "sacred ecology". Sacred ecology examines frames of knowledge held by indigenous and other rural peoples around the world. Berkes is explaining the importance of local and indigenous knowledge for sustainable management of protected areas (Berkes, 2012). Local guidance provides financial support to the local community. From these aspects and if provided in compliance with the rules, local guidance is an instrument that can be used successfully for the sustainable management of the protected areas.

Acknowledgements. This research did not receive any specific grant from funding agencies in the public, commercial, or not-for-profit sectors. I would like to thank forest engineer Ali MUTLU for his help in field work. The authors declare no conflict of interest.

\section{REFERENCES}

[1] Absher, J. (1989). Applying the limits of acceptable change model to national park service wilderness: An Example from Cumberland Island National Seahore. Proceedings of the 1988 Southeastern Recreation Conference, pp.143-152.

[2] Akten, S., Gül, A., Akten, M. (2012). The comparison of visitor management frameworks in protected natural areas. - Turkish Journal of Forestry 13: 57-65.

[3] Akyol, A., Tolunay, A. (2012). Evaluation of Yenişarbademli district (Isparta) potential and development of ecotourism sustainability. 2. National Rural Tourism Symposium, Aksaray, Turkey, 20-22 September 2012, pp. 25-36.

[4] Akyol, A., Türkoğlu, T., Tolunay, A., Efe, A. (2014). A forest village analyses for intervening to rural development: A case study from Turkey. - Works of the Faculty of Forestry Journal 44(2): 1-15. 
[5] Alkan, H. (2009). Negative impacts of rural settlements on natural resources in the protected areas: An example from Kovada Lake National Park. - Journal of Environmental Biology 30(3): 363-372.

[6] Alkan, H., Korkmaz, M. (2009). An Investigation for socioeconomics problems in management of protected areas. II. Socio-economic Problems Congress in Forestry, Isparta, Turkey, 19-21 February 2009, pp.13-22.

[7] Alkan, H., Korkmaz, M., Tolunay, A. (2009). Assessment of primary factors causing positive or negative local perceptions on protected areas. - Journal of Environmental Engineering and Landscape Management 17(1): 20-27.

[8] Ar1, Y. and Soykan, A. (2006a). The economic and social impacts of Kazdağ 1 National Park on local communities. Kazdağları 2. National Symposium, Çanakkale, Turkey, 2225 June 2006, pp.234-245.

[9] Ar1, Y., Soykan, A., (2006b). Cultural Ecology and Nature Conservation at Kazdağ National Park. - Turkish Journal of Geography 44:11-32.

[10] Arslan, Y. (2005). A study of ecotourism in Erdek region. - Balıkesir University the Journal of Social Sciences Institute 8(13): 29-53.

[11] Atay, L. (2006). Evaluation and implementation of local guidance activities related to the Gallipoli Peninsula Historical National Park. I. International Congress of Çanakkale, İstanbul, Turkey, 17-19 March 2006, volume II, pp.417-424.

[12] Atay, L. (2008). The implementation of local guidance at Çanakkale and its evaluation in terms of tourism related laws and regulations. Anatolia: A Journal of Tourism Research 19(2): 169-176.

[13] Badola, R., Barthwal, S., Hussain, S. A. (2012). Attitudes of local communities towards conservation of mangrove forests: A case study from the east coast of India. - Estuarine, Coastal and Shelf Science 96: 188-196.

[14] Bajracharya, S.B., Furley, P.A., Newton, A. C. (2005). Effectiveness of community involvement in delivering conservation benefits to the Annapurna Conservation Area, Nepal. - Environmental Conservation 32: 239-247.

[15] Berkes, F. (2012). Sacred Ecology. - Third edition published by Routledge, New York.

[16] BİKTM. (2016). Balıkesir Provincial Directorate of Cultural Tourism. Available online: http://www.balikesirkulturturizm.gov.tr/TR,65922/kaz-dagi-ida-dagi.html (accessed on 25. 03. 2016).

[17] Buckley, R. (2003). Pay to play in parks: an Australian Policy perspective on visitor fees in public protected areas. - Journal of Sustainable Tourism 11(1): 56-73.

[18] Buckley, R., Robinson, J., Carmody, J. (2008). Monitoring for management of conservation and recreation in Australian protected areas. - Biodiversity and Conservation 17: 3589-3606.

[19] Bushell, R., Eagles, P. (2007). Tourism and protected areas: benefits beyond boundaries. The Vth IUCN world parks congress. - CAB International, Oxford, 2007, pp. 349.

[20] Calvet-Mir, L., Maestre-Andrés, S., Molina, J., Van den Bergh, J. (2015). Participation in protected areas: a social network case study in Catalonia, Spain. - Ecology and Society 20(4): 45-56.

[21] CSGB. (2016). Ministry of Labour and Social Security. Available online: www.csgb.gov.tr/home/contents/istatistikler/asgariucret/ (accessed on 15. 06. 2016).

[22] Dirmenci, T., Sat1l, F., Tümen, G. (2004). Some endemic and rare species of Ida Mountain National Park. XVII. National Biology Congress, Adana, Turkey, 21-24 June 2004, pp.102.

[23] Dudley, N. (2008). Guidelines for Applying Protected Area Management Categories. (Editor) IUCN (International Union for Conservation of Nature), Gland, Switzerland, pp.x+86.

[24] GDNP. (2016). General Directorate Nature Conservation and Natural Parks. Available online: http://www.milliparklar.gov.tr/mp/kazdagi/?sflang=tr (accessed on 15. 03. 2016). 
[25] GGN. (2016). Guidelines and criteria for national geoparks seeking UNESCO's assistance to join the global geoparks network (GGN). Available online: http://www.europeangeoparks.org/wpcontent/uploads/2012/03/Geoparks_Guidelines_Jan2014.pdf (accessed on 17. 07. 2016).

[26] Gül, A., Akten, M. (2005). Recreational carrying capacity in protected natural areas: A conceptual approaches. Protected Natural Areas Symposium, Isparta, Turkey, 8-10 September 2005, pp. 485-494.

[27] Howard, J., Thwaites, R., Smith, B. (2001). Investigating the roles of the indigenous tour guide. - The Journal of Tourism Studies 12(2): 32-39.

[28] İslamoğlu, A. H. (2009). Social Science Research Methods. - Beta Press Release Distribution, İstanbul, 2009.

[29] IUCN. (2015). Protected Area Governance And Management. In Worboys, G.L., Lockwood, M., Kothari, A., Feary, S. and Pulsford, I. (eds). - ANU Press, Canberra,

[30] IUCN. (2016). IUCN protected areas categories system. Available online: https://www.iucn.org/theme/protected-areas/about/protected-areas-categories (accessed on 25. 06. 2016).

[31] Jones, C., Newsome, D., Macbeth, J. (2016). Understanding the conflicting values associated with motorized recreation in protected areas. - Ambio 45: 323-330.

[32] Kervankıran, İ., Eryılmaz, A. (2014). The use of national parks for recreational activities in the province of Isparta. - Marmara Geographical Review 29: 81-110.

[33] KMPAKD. (2016). Association of Local Guides of Kaz Mountain National Park. Available online: http://www.kazdagialanklavuzlari.com/ (accessed on 01. 06. 2016).

[34] Korkmaz, M., Başkalkan, S. N. (2011). Assessments on sustainability of tourism development in Eğirdir Lake region. - Turkish Journal of Forestry 12: 62-69.

[35] Kuss, F. R., Graefe, A. R. (1985). Effects of recreation trampling on natural area vegetation. -Journal of Leisure Research 17(3): 165-183.

[36] Kuss, F. R., Graefe, A. R., Vaske, J. J. (1990). Visitor Impact Management: A Review Of Research. - Washington, DC: National Parks and Conservation Association, USA.

[37] Liddle, M. J. (1997). Recreation ecology: the ecological impact of outdoor recreation and ecotourism. - Chapman and Hall Ltd.

[38] Lockwood, M., Worboys, G., Kothari, A. (2012). Managing Protected Areas: A Global Guide. - Routledge.

[39] Marzouki, M., Froger, G., Ballet, J. (2012). Ecotourism versus mass tourism. A comparison of environmental impacts based on ecological footprint analysis. Sustainability 4: 123-140.

[40] McGeoch, M. A., Genovesi, P., Bellingham, P. J., Costello, M. J., McGrannachan, C., Sheppard, A. (2016). Prioritizing species, pathways, and sites to achieve conservation targets for biological invasion. - Biological Invasions 18: 299-314.

[41] Mendes, M., Pala, A. (2003). Type I error Rate and power of three normality tests. Pakistan Journal of Information and Technology 2(2): 135-139.

[42] Ormsby, A., Mannle, K. (2006). Ecotourism benefits and the role of local guides at Masoala National Park, Madagascar. - Journal of Sustainable Tourism 14(3): 271-287.

[43] Özden, S., Alkan, H., Korkmaz, M. (2001). Socio-economic structure of the villages in the Kızıldağ National Park. - Rural Environment Yearbook 2: 34-47.

[44] Pickering, C. M., Hill, W. (2007). Impacts of recreation and tourism on plant biodiversity and vegetation in protected areas in Australia. - Journal of Environmental Management 85(4): 791-800.

[45] Pullin, A. S., Knight, T. M. (2005). Assessing conservation management's evidence base: a survey of management plan compilers in the United Kingdom and Australia. Conservation Biology 19: 1989-1996.

[46] RG. (2016a). Official gazette. Available online: http://www.resmigazete.gov.tr/eskiler/2014/03/20140306-5.htm (accessed on 28. 04. 2016). 
[47] RG. (2016b). Official gazette. Available online: http://www.resmigazete.gov.tr/eskiler/2010/08/20100821-5.htm (accessed on 28. 04. 2016).

[48] Sat1l, F., Dirmenci, T., Tümen, G. (2006). Classification of priority conservation areas Kazdağ National Park and their important plants. Kazdağları II. National Symposium, Çanakkale, Turkey, 22-25 June 2006, pp.391-401.

[49] Soykan, A., Ar1, Y. (2004). Ecotourism guide training in Ida Mountain National Park. 1. Balıkesir National Tourism Congress, Balıkesir, Turkey, 15-16 April 2004, pp.455-474.

[50] Stone, M. T., Nyaupane, G.P. (2016). Protected areas, tourism and community livelihoods linkages: a comprehensive analysis approach. - Journal of Sustainable Tourism 24(5): 673-693.

[51] Suich, H., Howe, C., Mace, G. (2015). Ecosystem services and poverty alleviation: a review of the empirical links. - Ecosystem Services 12: 137-147.

[52] Tağıl, Ş. (2006). Geomorphometric factors controlling landcover organization in Kazdă National Park: A GIS approach. - Journal of Geographical Sciences 4(2): 37-47.

[53] Temizkan, S.P., Yıldırım, G. (2014). The application of local guidance within the context of sustainable tourism: the case of National Park at the Kaçkar Mountains. Electronic Journal of Social Sciences 13(49): 124-149.

[54] Tolunay, A., Akyol, A. (2015). Identify of appropriate biodiversity indicators for ecologically sustainable forest management at national level. - Sains Malaysiana 44(2): 159-166.

[55] Tolunay, A., Alkan, H. (2008). Intervention to the misuse of land by the forest villages: A case study from Turkey. - Ekology 17(68): 1-10.

[56] Tolunay, A., Türkoğlu, T., Elbakidze, M. and Angelstam, P. (2014). Determination of the support level of local organizations in a model forest initiative: do local stakeholders have willingness to be involved in the model forest development? - Sustainability 6(10): 71817196.

[57] Törn, A., Siikamäki, P., Tolvanen, A., Kauppila, P., Rämet, J. (2007). Local people, nature conservation, and tourism in northeastern Finland. - Ecology and Society 13(1): 818.

[58] Trakolis, D. (2001). Perceptions, preferences, and reactions of local inhabitants in VikosAoos National Park, Greece. - Environmental Management 28: 665-676.

[59] Wang, L.-E., Zhong, L., Zhang, Y., Zhou, B. (2014). Ecotourism environmental protection measures and their effects on protected areas in China. - Sustainability 6: 6781-6798.

[60] Wells, M., McShane, T. O. (2004). Integrating protected area management with local needs and aspirations. - Ambio 33: 513-519.

[61] Yildirım, H. T., Yurdakul, E. S. (2012). Protected areas, ecologic functions and predictions towards future. - Research Journal of Biological Sciences 5: 101-109.

[62] Yüksel, A., Mil, B., Bilim, Y. (2007). Qualitative Research Why, How, Why. - Detay Publishing, Ankara.

[63] Yurdakul, E. S., Kuvan, Y., Yıldırım, H. T. 2011. The general characteristics and main problems of national parks in Turkey. - African Journal of Agricultural Research 6(23): $5377-5385$. 